\title{
Information Transmission between India and International Commodities Futures Market: An Empirical Study for Bullion and Metals
}

\author{
Neha Berlia ${ }^{1, *} \&$ Sanjay Sehgal ${ }^{2}$ \\ ${ }^{1}$ Swiss Institute of Banking and Finance, University of St. Gallen 9000, Switzerland \\ ${ }^{2}$ Department of Financial Studies, University of Delhi, New Delhi 110 021, India \\ *Corresponding author: Tel: 41-71 2220 116. E-mail: neha.berlia@student.unisg.ch \\ Received: October 29, 2013 Accepted: November 8, 2013 Published: December 20, 2013 \\ doi:10.5296/rae.v5i4.4797ＵRL: http://dx.doi.org/10.5296/rae.v5i4.4797
}

\begin{abstract}
This study examines the process of information transmission in futures prices of bullion (gold and silver) and metals (aluminum, copper, and zinc) between India, represented by MCX, and its global counterparts trading platforms, such as COMEX, LME, and SHFE, for the period of 2005 to 2012. Structural breaks are identified for all sample series, which capture the impact of the recent economic crisis on these commodity markets. The price discovery results confirm that there is a long-term equilibrium relationship among the futures prices of examined trading platforms in each commodity series, with the exception of aluminum. The MGARCH results of volatility spillovers indicate that, in the case of bullion, MCX seems to be more dominant than COMEX, implying that it is no longer a satellite market, while in case of metals, LME seems to play the dominant role followed by MCX and SHFE. The research contributes to the commodity market literature for emerging economies.
\end{abstract}

Keywords: Commodity futures market; Price discovery; Structural break; Volatility spillovers; MGARCH

JEL classification: C32, G12, G13 


\section{Introduction}

A large number of studies have examined the process of information transmission by analyzing the price discovery and volatility spillovers for both mature and emerging commodity markets (see Ross, 1989; Tse, 1998; Thomas and Karande, 2001; Chan et al. 2004; Lee et al. 2009; Hua and Chen. 2007; Ge et al. 2008; Fung et al. 2010; Dey and Maitra, 2011; Du et al. 2011; Liu and An, 2011; Kumar and Pandey, 2011). Price discovery is defined as the process which deals with flow of information from one market to another. Volatility spillovers are the means by which volatility in one market impacts that of another market. In recent years, strong upheavals in commodity prices, exacerbated by the global financial crisis, have attracted a great deal of attention of researchers and policymakers in examining price behavior in commodity markets, owing to their strong policy implications for market practitioners. In this study, we compare the process of information transmission in futures prices of bullion and metals in India with its global counterpart such as the Commodity Exchange Inc. (COMEX), London Metal Exchange (LME), and Shanghai Futures Exchange (SHFE). The study is motivated by the fact that globally, due to strong demand for bullion and metals in emerging economies owing to their high growth prospect, many of these economies have started setting up their own commodity exchanges, and, gradually, their share in total trade has been increasing consistently. In this light, the two most promising economies are India and China, whose commodity exchanges have recorded spectacular growth in recent years, and in some commodities their trading activity is enormously large vis-à-vis their counterparts, making them two of the strongest trading platforms in the world. We specifically investigate price discovery and volatility spillover between Indian commodity market and international markets. The study proxies the Indian commodity market by using the data from the Multi-Commodity Exchange (MCX), because it is the largest futures trading platform in the country for bullion and metals. The study also focuses on India because it has one of the fastest growing commodity markets in the world, and it is currently competing in bullion and metals with leading global platforms such as COMEX, LME, and SHFE. The Indian economy has been growing at an impressive rate of more than $9 \%$ in the last decade. Despite the fragile recovery of the United States and European economies, the economy has still not weakened its growth momentum, and is expected to achieve a growth rate of $6.1 \%$ in 2012 and $6.5 \%$ in 2013, as projected by the International Monetary Fund (IMF, 2012). The economy is also seeing one of the largest commodity markets augmented by high agricultural growth and increased demand for metals, bullion, and energy products for industrial and domestic purposes.

In this study, we focus on bullion and metals, as these are the most actively traded commodities in India and account for 63\% (38\% bullions and 25\% metals) of the average daily trading volume. It may be noted that agricultural commodities and energy products account for only $25 \%$ and $12 \%$ of the trading volumes, respectively, on the Indian commodity exchanges. In India, MCX is the largest trading platform for bullion, metals, and energy products. In recent time, MCX has recorded the highest trading volume in gold and silver among all world-trading exchanges. The National Commodity \& Derivatives Exchange (NCDEX) is the most active exchange for agricultural commodities. The criteria for selection 
of sample commodities from the bullion and metals category are as follows: a). India should be among the five largest producers/consumers of a given commodity. b). The Indian commodity exchange should figure among the top three trading platforms, based on trading activity for a given commodity. c). The average daily trading volume should be 0.1 million or more in terms of respective commodity units.

The third criterion ensures that there is enough market depth for a traded commodity. All bullion and metals that satisfy either criterion (a) or (b) and, in addition, satisfy criterion (c) have been shortlisted. Five commodities are selected: gold, silver, aluminum, copper, and zinc. The commodity exchanges have been selected based on the level of trading activity exhibited for sample commodities. In the case of bullion, MCX competes with COMEX and Tokyo Commodity Exchnage (TOCOM). Since COMEX and MCX are the two largest trading platforms in the case of bullion, they have been chosen to study the price discovery and volatility spillovers in futures prices. In the case of metals, LME and SHFE are two competitive markets for MCX. Though, LME and SHFE metals markets are relatively more developed than MCX, the share of MCX is increasing and, in the case of zinc, it is almost closer to LME and SHFE. It may here be noted that we have included LME and SHFE as the proxy markets for international commodity exchange, given their international importance for metals.

The following are the major objectives of this study: a). To evaluate if there are any structural breaks in the time series of futures prices of sample commodities. b). To examine the process of price discovery between MCX and COMEX for bullion (gold and silver), and between MCX, LME, and SHFE of metals (aluminum, copper, and zinc). c). To investigate if there are any short- and long-term volatility spillovers between MCX and COMEX in case of bullion and the three exchanges for metals.

The paper is comprised of six sections, including the present one. A brief review of literature is provided in Section 2. Section 3 covers data and their sources, while methodology and estimation procedures are described in Section 4. In Section 5, we provide empirical results, followed by a summary and conclusion in the last section.

\section{Review of Literature}

A large number of studies have examined the price discovery and volatility spillovers under two broad frameworks. Firstly, under within market, examining the relationship between spot and futures (see Gagnon and Karolyi, 2006).(Note 1) Secondly, between markets (futures price linkages) for an identical asset (see Hasbrouck, 1995; Lihara et al. 1996; Ding et al. 1999; Tse, 1998; Roope and Zurbruegg, 2002; Xu and Fung, 2005, among others). The early studies focused on examining the market within, specifically, the relationship between spot and futures prices. The examination of information transmission between markets helps investors to identify the dominant and satellite markets through which they try to exhibit the role of dominant exchange in the price discovery and volatility spillover of an identical asset. In this regard, a seminal study of Garbade and Silber (1979) on stock market linkages could 
be considered as the pioneer work highlighting, the role of the short-run behavior of an identical asset traded in two different markets, i.e. the New York Stock Exchange (NYSE) and the regional stock exchanges, by way of considering the NYSE as the dominant and regional stock exchanges as the satellite markets. In another study, Eun and Shim (1989) examined how the information transmission could lead to dominance in the futures market. Their study concluded that the U.S. equity market dominates the rest of the world in terms of information transmission. In later perids, some important studies also examined this issue in a cross country settings and considerably large set of assets (see, King and Wadhwani, 1990; Susmel and Engle, 1994; Koutmos and Booth, 1995; Booth et al. 1996; Booth and Ciner, 1997; Booth et al. 1998; Tse, 1999; Low et al. 1999; Fung et al. 2001, among others). It may here be noted that most studies in the literature have examined the process of information transmission in mature market setting and very few studies have highlighted the role of price discovery and volatility spillover in emerging market context particularly the commodity market. In this regard, in a significant study, Fung et al. (2003) confirmed the volatility spillovers between mature (US) and emerging markets (China) for three commodities futures viz., copper, soybeans, and wheat. Their study concluded that in case of copper and soybeans, the U.S. futures market played a dominant role in transmitting information to the Chinese market while in case of wheat both market found to be segmented. Hua and Chen (2007) investigated the international linkages of Chinese commodity futures markets in case of aluminum, copper, soybean, and wheat. Considering Chicago Board of Trade (CBOT) and London Metal Exchange (LME) as counterpart markets for agri and non-agri commodities, they reported that aluminum, copper, and soybean futures prices were integrated with spot prices, but they did not find such cointegration in case of wheat spot and futures prices. Ge et al. (2008) examined the dynamic linkages between the cotton futures markets of China and the United States. Their study reported both markets as strongly linked market. Du et al. (2011) examined the important factors that impact crude oil volatility, and investigated the possible linkages between crude oil volatility and agricultural commodities. Their study found sufficient evidence of volatility spillovers for sample commodities. Liu and An (2011) examined information transmission and price discovery in informationally linked markets. Using data on both synchronous and non-synchronous trading from Chinese futures/spot markets, the New York Mercantile Exchange (NYMEX), Chicago Board of Trade (CBOT), and CME Globex futures markets for copper and soybeans, their study found evidence of bi-directional volatility spillovers between USA and Chinese markets, moving strongly from USA to Chinese markets.

With regard to India, there are very few studies that have examined the information transmission mechanism in the context of Indian commodity market. As above mentioned, empirical literature on price discovery and volatility spillover mainly deals with developed markets like USA and UK. In case of India, significant and relevant literature on the commodity market is sparse, and has mainly focused on agricultural commodities (see Thomas and Karande, 2001; Naik and Jain, 2002; Kabra, 2007; Roy, 2008; Ghosh, 2009a, 2009b, 2010; Roy and Dey, 2009; Mahalik et al. 2010; Dey and Maitra, 2011). Further, Indian literature is limited to regional exchanges and covers small samples from the period 
prior to the establishment of national exchanges, or to very few commodities traded on these exchanges. Pertinent to the objectives of the present study, the study of Kumar (2004) examined the price discovery and reported the inability of futures markets to fully incorporate information and confirmed that they are not fully efficient. In another important study, Kumar and Pandey (2011) examined the international linkages of the Indian commodity futures market with its offshore counterparts markets viz., CBOT, LME and NYMEX. They reported that world markets have a bigger (unidirectional) impact on Indian markets.

To summarize, the literature on price discovery and volatility spillover, which rests upon the process of information transmission, it is clear that while there is broad consensus on the role of information linkages across markets, the issue still appears to be unsettled especially in the light of the recent trubulent periods which have jolted the commodity markets across globe. Further, there is very limited study on information transmission between emerging markets like India and important international commodity exchanges. Hence, the research issue needs to be empirically addressed. Futures markets in emerging countries are characterized by low liquidity and less efficient trading systems (see Tomek, 1980; Carter, 1989), making them different from the counterpart markets in mature countries. In the Indian context, prior research on the subject (see Kumar and Pandey, 2011) has used data through 2008. It may be noted that Indian commodity futures exchanges began trading only in 2004 and, hence, are of nascent origin. The period from 2009 to the present, which has been relatively unexplored, is of great importance, as it is the time when these trading platforms have achieved a higher level of trading liquidity, and there may be a strengthening of international linkages. The present study attempts to fill these important research gaps by examining the information transmission between MCX (in India) and prominent international commodity exchanges for select bullion and metals using longer data periods and contemporary econometric techniques.

\section{Methodology}

\subsection{Process of Price Discovery}

At the first stage, stationarity conditions using conventional methods of unit root tests-Augmented Dickey Fuller (ADF), Phillips-Perron (PP) and Kwiatkowski-Phillips-Schmidt-Shin (KPSS) tests - have been checked for all commodities under consideration, followed by structural break unit root tests, in order to identify any abnormal events during sample period. For this purpose, Zivot-Andrews (hereafter ZA, 1992) unit root test and Gregory and Hansen (1996) test of cointegration with structural break have been employed (see Glynn et al. 2007 and Cook, 2006, for details).(Note 2) The results of the GH test (1996) are further confirmed by the Johansen cointegration (1992) test and the Vector Error Correction Model (VECM), as mentioned in equations (1) and (2). The bivariate cointegrated series $P_{t}=\left(F_{1, t}, F_{2, t}\right)^{\prime}$, is represented by a vector error correction model (VECM): 


$$
\begin{aligned}
& \Delta F_{1, t}=b_{1}+\beta_{1} E C_{t-1}+\sum_{i=1}^{k} d_{1 i} \Delta F_{1, t-i}+\sum_{i=1}^{k} g_{1 i} \Delta F_{2, t-i}+\mathcal{E}_{1 t} \\
& \Delta F_{2, t}=b_{2}+\beta_{2} E C_{t-1}+\sum_{i=1}^{k} d_{2 i} \Delta F_{1, t-i}+\sum_{i=1}^{k} g_{2 i} \Delta F_{2, t-i}+\varepsilon_{2 t}
\end{aligned}
$$

Note that $E C_{t-1}=F_{1, t-1}-a-b F_{2, t-1}$ is the lagged error correction term.

Given the large number of parameters that would have to be estimated in the volatility spillover model (as discussed in subsection 3.2), a two-step procedure similar to that implemented by Bekaert and Harvey (1997), Ng (2000), and Baele (2005) has been considered in this study. In the first step, the vector error correction model is estimated to obtain estimates of the shock vector for futures prices. In the second step, the first-stage residuals are used as data to check for volatility spillover between the futures prices of both markets.

\subsection{Process of Volatility Spillovers}

Numerous studies have investigated the process of volatility spillover to understand the spread of shock originating from one market to other. Most studies in the literature have used different variants of GARCH models to examine the volatility spillover between markets (see Hamao et al. 1990; Lin et al. 1994; Koutmos and Booth, 1995; Booth et al. 1997; Christofi and Pericli, 1999; Engle et al. 1990). According to Chan et al. (1991), it is the volatility that determines the flow of information from one market to another and not just the simple price change. (Note 3)

The BEKK model is used as a benchmark to examine the volatility spillovers (see Wang, 2009). The other models, e.g., CCC (Constant Conditional Correlation) and DCC, are used to substantiate the BEKK results under the VARMA-GARCH (see Ling and McAleer, 2003) framework. We use the VARMA approach for CCC and DCC because such an approach of modeling conditional variances permits large shocks to one variable to affect the variances of other variables. Hence, this helps in substantiating BEKK results vis-à-vis CCC and DCC models to demonstrate volatility spillovers. Under this approach the variance terms take the form of (for a 1, 1 model):

Mean equation:

$$
v_{i t}=\mu_{i 0}+\sum_{j=1}^{5} \mu_{i j} v_{j, t-1}+\varepsilon_{i t} \ldots \ldots \ldots . .(3), \text { where } \varepsilon_{i t} \mid I_{i t-1} \square N\left(0, h_{i t}\right), i=1,2,3,4,5
$$

In equation (3), $v_{i t}$ is the estimated residual of the sample series. $\varepsilon_{i t}$ is a random error term with conditional variance $h_{i t}$. $I_{i t-1}$ denotes the market information at time t-1. Equation (4) 
specifies the variance equation. $i=1,2,3,4,5$ shows the number of sample commodities analyzed pairwise.

Variance equation:

$$
H_{i t}=c_{i i}+\sum_{j=1}^{5} \alpha_{i j} \mathcal{E}_{j, t-1}^{2}+\sum_{j=1}^{5} \beta_{i j} H_{j j(t-1)}
$$

This is a convenient specification that allows for volatility spillovers (see Sadorsky, 2012). $c_{i i}$ denotes the constant terms, $\alpha$ denotes the ARCH terms and $\beta$ denotes the GARCH terms. The coefficient $\alpha_{12}$, for example, represents the short-term volatility spillover from one market to another (say, for example, MCX to LME), while $\beta_{12}$ represents the long-term volatility spillover in the same manner as mentioned above. It may be noted that under Ling and McAleer (2003) approach of modeling the conditional variances allows lage shocks to one variable to affect the variances of the other variables. This is convenient specification which allows for volatility spillovers. The Engle (2002) dynamic conditional correlation (DCC) model is estimated in two steps. In the first step, GARCH parameters are estimated. In the second steps correlations are estimated.

$$
H_{t}=D_{t} R_{t} D_{t}
$$

In equation (5), $H_{t}$ is the $3 \times 3$ conditional covariance matrix as in our case, $R_{t}$ is the conditional correlation matrix and $D_{t}$ is a diagonal matrix with time-varying standard deviations on the diagonal.

$$
\begin{aligned}
& D_{t}=\operatorname{diag}\left(h_{11 t}{ }^{1 / 2} \ldots . h_{33 t}{ }^{1 / 2}\right) \\
& R_{t}=\operatorname{diag}\left(q_{11 t}{ }^{-1 / 2} \ldots . . q_{33 t}{ }^{-1 / 2}\right) Q_{t} \operatorname{diag}\left(q_{11 t}{ }^{-1 / 2} \ldots . . q_{33 t}{ }^{-1 / 2}\right)
\end{aligned}
$$

Where $Q_{t}$ is a symmetric positive definite matrix:

$$
Q_{t}=\left(1-\theta_{1}-\theta_{2}\right) \bar{Q}+\theta_{1} \varepsilon_{t-1} \varepsilon_{t-1}^{\prime}+\theta_{2} Q_{t-1}
$$

$\bar{Q}$ is the $3 \times 3$ unconditional correlation matrix of the standardized residuals $\varepsilon_{i t}$. The parameters $\theta_{1}$ and $\theta_{2}$ are non-negative with a sum of less than unity. Under the condition of $R_{t}=R$ and $R_{i j}=\rho_{i j}$ equation (7) becomes constant conditional correlation (CCC) model. 


$$
\rho_{i j t}=\frac{q_{i j t}}{\sqrt{q_{i i t} q_{j j t}}}
$$

The MGARCH models are estimated by Quasi-Maximum Likelihood Estimation (QMLE) using the BFGS algorithm. $\mathrm{T}$ statistics are calculated using a robust estimate of the covariance matrix (see Sadorsky, 2012).

\section{Data Description}

The sample data for the daily futures prices of MCX, COMEX, LME, and SHFE for five commodities, including two precious metals (gold and silver) and three non-precious metals (aluminum, copper, and zinc), are retrieved from the Bloomberg database. We use the data of gold and silver traded on COMEX and aluminum, copper and zinc futures price traded on LME and SHFE as the counterpart markets for Indian futures markets. All closing prices of futures series are taken for the nearest contract to maturity. Based on the availability of the data, the sample period of each commodity is as follows: aluminum (October 26, 2005, to April 27, 2012; 1,581 observations); copper (January 4, 2005, to April 27, 2012, 1,766; observations); gold and silver (January 3, 2005 to April 30, 2012, 1,851 and 1,855 observations, respectively); and zinc (March 27, 2007 to April 27, 2012; 1,237 observations). In order to maintain parity across sample markets, all price series have been converted into U.S. dollars after making the adjustment in terms of units of measurement.(Note 4) For estimation purpose, all price series are further converted into natural logarithms.

\section{Empirical Results}

We begin by examining the plot of commodity futures prices observed at sample trading platforms over the study period. In the descriptive statistics for sample commodity returns shown in Table 1, the mean returns of sample commodities are positive, with the exception of zinc, in all markets.(Note 5) The highest mean daily returns are observed in the case of silver at MCX and COMEX $(0.084 \%$ and $0.082 \%)$, followed by gold at MCX and COMEX $(0.074 \%$ and $0.073 \%$ ), respectively. The lowest average returns are found in the cases of zinc at LME $(-0.038 \%)$, followed by MCX and SHFE $(-0.037 \%$ and $-0.035 \%)$, respectively. Mean returns for sample commodities are almost similar across competing trading platforms, with the exception of aluminum. SHFE returns in the case of aluminum are almost three and four times larger than those observed for LME and MCX. The standard deviation as a measure of volatility is highest for silver $(2.43 \%)$ at MCX, followed by zinc at LME $(2.39 \%)$ and MCX $(2.38 \%)$. The skewness coefficients of all metals are negative, except aluminum and zinc for MCX, highlighting the negative impacts of a series of economic crises observed in recent times, including the ongoing upheaval in Europe. All returns series are leptokurtic and violate normality, as exhibited by Jarque-Bera (JB) statistics. This is further substantiated by the results of $\mathrm{ARCH}$ effects, which confirm the presence of clustering in all examined 
commodities. The Ljung Box (LB) test further indicates autocorrelation in the sample series, especially in squared returns up to 10 lags.

Table 1: Descriptive Statistics of sample commodities

\begin{tabular}{|c|c|c|c|c|c|c|c|c|c|c|c|c|c|}
\hline & Aluminum & & & & Copper & & & Zinc & & Gold & & Silver & \\
\hline & SHFE & LME & MCX & SHFE & LME & MCX & SHFE & LME & MCX & COMEX & MCX & COMEX & MCX \\
\hline Mean & 0.012 & 0.004 & 0.003 & 0.042 & 0.046 & 0.044 & -0.035 & -0.038 & -0.037 & 0.073 & 0.074 & 0.082 & 0.084 \\
\hline Max. & 5.184 & 7.522 & 9.388 & 6.630 & 11.507 & 10.767 & 5.819 & 9.651 & 14.170 & 8.625 & 8.721 & 9.237 & 12.196 \\
\hline Min. & -7.198 & -10.912 & -8.598 & -8.824 & -20.469 & -19.270 & -6.609 & -15.886 & -11.734 & -7.581 & -7.915 & -18.387 & -19.546 \\
\hline Std.Dev. & 1.091 & 1.656 & 1.774 & 1.708 & 2.167 & 2.162 & 1.725 & 2.395 & 2.381 & 1.319 & 1.202 & 2.085 & 2.432 \\
\hline Skewness & -0.545 & -0.182 & 0.311 & -0.353 & -0.656 & -0.467 & -0.409 & -0.155 & 0.054 & -0.271 & -0.175 & -1.415 & -0.974 \\
\hline Kurtosis & 7.847 & 5.577 & 6.249 & 5.025 & 9.858 & 9.318 & 4.078 & 5.564 & 6.454 & 6.815 & 7.961 & 14.674 & 9.047 \\
\hline JB & 1625.983 & 446.264 & 721.082 & 338.274 & 3587.128 & 3001.768 & 94.446 & 343.799 & 615.641 & 1145.054 & 1907.949 & 11151.650 & 3119.718 \\
\hline \multirow[t]{2}{*}{ Prob. } & {$[0.000]$} & {$[0.000]$} & {$[0.000]$} & {$[0.000]$} & {$[0.000]$} & {$[0.000]$} & {$[0.000]$} & {$[0.000]$} & {$[0.000]$} & {$[0.000]$} & {$[0.000]$} & {$[0.000]$} & {$[0.000]$} \\
\hline & 53.769 & 7.683 & 16.236 & 23.463 & 5.386 & 8.773 & 6.468 & 0.889 & 0.242 & 20.856 & 24.903 & 16.920 & 35.269 \\
\hline \multirow[t]{2}{*}{ Arch } & {$[0.000]^{* *}$} & {$[0.000]^{* *}$} & {$[0.000]^{* *}$} & {$[0.000]^{* *}$} & {$[0.000]^{* *}$} & {$[0.000]^{* *}$} & {$[0.000]^{* *}$} & {$[0.488]$} & [0.943] & {$[0.000]^{* *}$} & {$[0.000]^{* *}$} & {$[0.000]^{* *}$} & {$[0.000]^{* *}$} \\
\hline & 48.437 & 5.575 & 5.669 & 21.329 & 9.626 & 29.811 & 28.802 & 2.952 & 6.582 & 17.544 & 11.896 & 8.991 & 18.331 \\
\hline \multirow[t]{2}{*}{ LB } & {$[0.000]^{* *}$} & [0.849] & {$[0.842]$} & {$[0.018]^{*}$} & {$[0.473]$} & {$[0.000]^{* *}$} & {$[0.001]^{* *}$} & [0.982] & {$[0.764]$} & {$[0.063]$} & {$[0.292]$} & {$[0.532]$} & {$[0.049]^{*}$} \\
\hline & 642.600 & 79.976 & 221.652 & 323.648 & 60.430 & 82.033 & 49.400 & 7.816 & 2.212 & 227.179 & 239.137 & 165.168 & 259.753 \\
\hline $\mathrm{LB}^{2}$ & {$[0.000]^{* *}$} & {$[0.000]^{* *}$} & {$[0.000]^{* *}$} & {$[0.000]^{* *}$} & {$[0.000]^{* *}$} & {$[0.000]^{* *}$} & {$[0.000]^{* *}$} & {$[0.646]$} & [0.994] & {$[0.000]^{* *}$} & {$[0.000]^{* *}$} & {$[0.000]^{* *}$} & {$[0.000]^{* *}$} \\
\hline Obs. & 1581 & 1581 & 1581 & 1766 & 1766 & 1766 & 1237 & 1237 & 1237 & 1851 & 1851 & 1855 & 1855 \\
\hline
\end{tabular}

Note: $* *$ denotes level of significance at $1 \%$ and better. Values in parentheses [ ] indicate the p-values.

$\mathrm{JB}=$ Jarque Bera and $\mathrm{LB}=\mathrm{Ljung}$ Box. $\mathrm{LB}$ statistics is reported up to 10 lags.

\subsection{Tests of Stationarity and Price Discovery Process}

Stationarity conditions of the sample commodity futures price series expressed in logarithmic form are tested by conventional ADF (unit root test) at the $1 \%$ level of significance. The ADF test confirms the existence of unit root at level and achieves stationarity at the first difference.(Note 6) The results of the ADF test are reconfirmed by additional tests of stationarity, that is, PP and KPSS tests. It shall be noted that the unit root results may be suspect when the sample period under analysis may have witnessed major events (e.g., a global economic crisis sovereign debt defaults, currency devaluation, regulatory shocks, etc.), which are likely to create structural breaks in a particular series. In order to account for any possible regime shifts resulting from structural breaks, the ZA unit root test has been implemented on sample commodity series. The results are shown in Table 2. It can be observed that most of the structural breaks identified by ZA test highlight the impact of the U.S. born global financial crisis and its aftermath. The possible reason could be a sudden fall in global demand of these commodities, due to the gloomy economic outlook of major consuming countries. 
Table 2: Zivot-Andrews Structural breaks unit root results

\begin{tabular}{llll}
\hline Variables & & At level & Break period \\
\cline { 1 - 1 } \cline { 1 - 1 } COMEX_gold & & -5.003 & $16-07-2008$ \\
MCX_gold & & -5.009 & $22-07-2008$ \\
COMEX_silver & & -4.467 & $15-07-2008$ \\
MCX_silver & & -4.309 & $15-07-2008$ \\
SHFE_alum & & -5.002 & $25-08-2008$ \\
LME_alum & & -4.255 & $14-07-2008$ \\
MCX_alum & & -4.197 & $14-07-2008$ \\
SHFE_copper & & -3.304 & $25-08-2008$ \\
LME_copper & & -3.290 & $04-07-2008$ \\
MCX_copper & & -3.322 & $03-07-2008$ \\
SHFE_zinc & & -3.780 & $20-03-2009$ \\
LME_zinc & & -4.304 & $03-03-2009$ \\
MCX_zinc & -4.265 & $02-03-2009$ \\
\hline \multicolumn{3}{c}{ 1\% } & Critical Values \\
\hline \multicolumn{3}{c}{$5 \%$} & -5.570 \\
\hline
\end{tabular}

Note: All series exhibit non-stationarity, confirming the use of co-integration with regime shifts.

After the ZA test, we move to analyze the price discovery process exhibiting the lead-lag relationship between the futures prices of examined markets. Keeping in mind the importance of structural breaks, we apply the GH cointegration test with regime shifts. The GH test provides the structural break dates for sample series, as shown in Table 3. The structural breaks identified by $\mathrm{GH}$ test highlight the contraction and expansion phases of global economy and more importantly the European crisis period for sample commodities. Despite the number of structural breaks for each commodity, the GH cointegration test indicates long-term cointegration relationships for all commodities and all trading platforms estimated pair-wise, except in case of SHFE-MCX and LME-SHFE for aluminum. These negative results do not come as a surprise given the abnormal return for aluminum observed at SHFE and the absence of matching structural break dates between these two pairs of platforms over the study, as shown above. The results of the GH test are further confirmed by the Johansen and Juselius (1992) test of cointegration on futures prices of five commodities (see Table 4). The results indicate that commodity futures prices across trading platforms, with exceptions, are the same as GH test, and exhibit long-term equilibrium relationships, thus confirming an efficient price discovery process. 
Table 3: Gregory and Hansen co-integration test

\begin{tabular}{|c|c|c|}
\hline Variables & t-stat & Period \\
\hline MCX_gold on COMEX_gold & $-10.376^{* *}$ & 04-09-2007 \\
\hline COMEX_gold on MCX_gold & $-10.433 * *$ & $01-12-2008$ \\
\hline MCX_silver on COMEX_silver & $-7.370 * *$ & 05-04-2006 \\
\hline COMEX_silver on MCX_silver & $-7.479 * *$ & 05-04-2006 \\
\hline SHFE_alum on LME_alum & $-5.184 *$ & 24-01-2011 \\
\hline LME_alum on SHFE_alum & -4.734 & 28-04-2011 \\
\hline MCX_alum on LME_alum & $-10.821 * *$ & 29-03-2007 \\
\hline LME_alum on MCX_alum & $-10.988 * *$ & $29-03-2007$ \\
\hline MCX_alum on SHFE_alum & -4.569 & $05-12-2008$ \\
\hline SHFE_alum on MCX_alum & -4.602 & 09-05-2011 \\
\hline SHFE_copper on LME_copper & $-5.823 * *$ & $15-02-2006$ \\
\hline LME_copper on SHFE_copper & $-5.713 * *$ & $22-08-2006$ \\
\hline MCX_copper on LME_copper & $-10.749 * *$ & 01-11-2006 \\
\hline LME_copper on MCX_copper & $-10.773 * *$ & $01-11-2006$ \\
\hline MCX_copper on SHFE_copper & $-6.002 * *$ & $21-08-2006$ \\
\hline SHFE_copper on MCX_copper & $-6.097 * *$ & $21-08-2006$ \\
\hline SHFE_zinc on LME_zinc & $-5.139 *$ & 24-12-2008 \\
\hline LME_zinc on SHFE_zinc & $-5.156^{*}$ & 24-12-2008 \\
\hline MCX_zinc on LME_zinc & $-11.907 * *$ & $16-01-2008$ \\
\hline LME_zinc on MCX_zinc & $-11.904 * *$ & $18-01-2008$ \\
\hline MCX_zinc on SHFE_zinc & $-5.219 * *$ & 24-12-2008 \\
\hline SHFE_zinc on MCX_zinc & $-5.139 * *$ & 24-12-2008 \\
\hline \multicolumn{3}{|c|}{\begin{tabular}{|c|} 
Significance level critical values \\
\end{tabular}} \\
\hline $1 \%$ & -5.47 & \\
\hline $5 \%$ & -4.95 & \\
\hline
\end{tabular}

Note: $* *$ indicates the level of significance at $1 \%$. EG based GH test considers dependent and independent variable like linear regression.

Table 4: Johansen's Cointegration results

\begin{tabular}{|c|c|c|c|c|c|c|c|}
\hline \multicolumn{4}{|c|}{ Trace test } & \multicolumn{4}{|c|}{ Maximum Eigen value test } \\
\hline Null & Alternative & Statistics & $\begin{array}{l}95 \% \\
\text { critical } \\
\text { value }\end{array}$ & Null & Alternative & Statistics & $\begin{array}{c}95 \% \\
\text { critical } \\
\text { value }\end{array}$ \\
\hline \multicolumn{8}{|c|}{ Cointegration between SHFE_alum and LME_alum } \\
\hline $\mathrm{r}=0$ & $\mathrm{r}>=1$ & 16.554 & 20.262 & $\mathrm{r}=0$ & $\mathrm{r}=1$ & 12.526 & 15.892 \\
\hline $\mathrm{r}<=1$ & $\mathrm{r}>=2$ & 4.028 & 9.165 & $\mathrm{r}<=1$ & $\mathrm{r}=2$ & 4.028 & 9.165 \\
\hline $\mathrm{r}<=2$ & $r>=3$ & & & $\mathrm{r}<=2$ & $\mathrm{r}=3$ & & \\
\hline \multicolumn{8}{|c|}{ Cointegration between MCX_alum and LME_alum } \\
\hline $\mathrm{r}=0$ & $\mathrm{r}>=1$ & $94.956^{*}$ & 15.495 & $\mathrm{r}=0$ & $\mathrm{r}=1$ & $91.940 *$ & 14.265 \\
\hline $\mathrm{r}<=1$ & $\mathrm{r}>=2$ & 3.016 & 3.841 & $\mathrm{r}<=1$ & $\mathrm{r}=2$ & 3.016 & 3.841 \\
\hline
\end{tabular}




$\mathrm{r}<=2 \quad \mathrm{r}>=3 \quad \mathrm{r}<=2 \quad \mathrm{r}=3$

Cointegration between SHFE_alum and MCX_alum

$\begin{array}{llccllll}\mathrm{r}=0 & \mathrm{r}>=1 & 23.334 & 25.872 & \mathrm{r}=0 & \mathrm{r}=1 & 18.058 & 19.387 \\ \mathrm{r}<=1 & \mathrm{r}>=2 & 5.276 & 12.518 & \mathrm{r}<=1 & \mathrm{r}=2 & 5.276 & 12.518 \\ \mathrm{r}<=2 & \mathrm{r}>=3 & & & \mathrm{r}<=2 & \mathrm{r}=3 & & \end{array}$

Cointegration between SHFE_copper and LME_copper

$\begin{array}{llllllll}\mathrm{r}=0 & \mathrm{r}>=1 & 36.991^{*} & 15.495 & \mathrm{r}=0 & \mathrm{r}=1 & 32.761 * & 14.265 \\ \mathrm{r}<=1 & \mathrm{r}>=2 & 4.231^{*} & 3.841 & \mathrm{r}<=1 & \mathrm{r}=2 & 4.231^{*} & 3.841 \\ \mathrm{r}<=2 & \mathrm{r}>=3 & & & \mathrm{r}<=2 & \mathrm{r}=3 & & \end{array}$

Cointegration between MCX_copper and LME_copper

$\begin{array}{llllllll}\mathrm{r}=0 & \mathrm{r}>=1 & 89.341^{*} & 15.495 & \mathrm{r}=0 & \mathrm{r}=1 & 85.046^{*} & 14.265 \\ \mathrm{r}<=1 & \mathrm{r}>=2 & 4.295^{*} & 3.841 & \mathrm{r}<=1 & \mathrm{r}=2 & 4.295^{*} & 3.841 \\ \mathrm{r}<=2 & \mathrm{r}>=3 & & & \mathrm{r}<=2 & \mathrm{r}=3 & & \end{array}$

Cointegration between SHFE_copper and MCX_copper

$\begin{array}{llllllll}\mathrm{r}=0 & \mathrm{r}>=1 & 41.287^{*} & 15.495 & \mathrm{r}=0 & \mathrm{r}=1 & 36.960 * & 14.265 \\ \mathrm{r}<=1 & \mathrm{r}>=2 & 4.327^{*} & 3.841 & \mathrm{r}<=1 & \mathrm{r}=2 & 4.327 * & 3.841 \\ \mathrm{r}<=2 & \mathrm{r}>=3 & & & \mathrm{r}<=2 & \mathrm{r}=3 & & \end{array}$

Cointegration between $S H F E \_z i n c$ and $M C X \_z i n c$

$\begin{array}{llllllll}\mathrm{r}=0 & \mathrm{r}>=1 & 20.094 * & 15.495 & \mathrm{r}=0 & \mathrm{r}=1 & 15.951 * & 14.265 \\ \mathrm{r}<=1 & \mathrm{r}>=2 & 4.143^{*} & 3.841 & \mathrm{r}<=1 & \mathrm{r}=2 & 4.143 * & 3.841 \\ \mathrm{r}<=2 & \mathrm{r}>=3 & & & \mathrm{r}<=2 & \mathrm{r}=3 & & \end{array}$

Cointegration between MCX_zinc and LME_zinc

$\begin{array}{lllllllc}\mathrm{r}=0 & \mathrm{r}>=1 & 80.663 * & 15.495 & \mathrm{r}=0 & \mathrm{r}=1 & 76.719 * & 14.265 \\ \mathrm{r}<=1 & \mathrm{r}>=2 & 3.944^{*} & 3.841 & \mathrm{r}<=1 & \mathrm{r}=2 & 3.944 * & 3.841 \\ \mathrm{r}<=2 & \mathrm{r}>=3 & & & \mathrm{r}<=2 & \mathrm{r}=3 & & \end{array}$

Cointegration between SHFE_zinc and LME_zinc

$\begin{array}{llllllrr}\mathrm{r}=0 & \mathrm{r}>=1 & 19.892 * & 15.495 & \mathrm{r}=0 & \mathrm{r}=1 & 15.593 * & 14.265 \\ \mathrm{r}<=1 & \mathrm{r}>=2 & 4.298^{*} & 3.841 & \mathrm{r}<=1 & \mathrm{r}=2 & 4.298 * & 3.841 \\ \mathrm{r}<=2 & \mathrm{r}>=3 & & & \mathrm{r}<=2 & \mathrm{r}=3 & & \end{array}$

Cointegration between COMEX_gold and MCX_gold

$\begin{array}{llcclcrc}\mathrm{r}=0 & \mathrm{r}>=1 & 64.658^{*} & 15.495 & \mathrm{r}=0 & \mathrm{r}=1 & 64.031 * & 14.265 \\ \mathrm{r}<=1 & \mathrm{r}>=2 & 0.627 & 3.841 & \mathrm{r}<=1 & \mathrm{r}=2 & 0.627 & 3.841 \\ \mathrm{r}<=2 & \mathrm{r}>=3 & & & \mathrm{r}<=2 & \mathrm{r}=3 & & \end{array}$

Cointegration between COMEX_silver and MCX_silver

$\begin{array}{llccllrc}\mathrm{r}=0 & \mathrm{r}>=1 & 49.248^{*} & 15.495 & \mathrm{r}=0 & \mathrm{r}=1 & 47.767 * & 14.265 \\ \mathrm{r}<=1 & \mathrm{r}>=2 & 1.482 & 3.841 & \mathrm{r}<=1 & \mathrm{r}=2 & 1.482 & 3.841 \\ \mathrm{r}<=2 & \mathrm{r}>=3 & & & \mathrm{r}<=2 & \mathrm{r}=3 & & \end{array}$

Notes: a) * indicates level of significance at $1 \%$, based of which order of integration is decided.

b). The lag structure is decided based on the minimum values of the Akaike information Criterion. 
Table 5: Estimated co-efficient of VEC model

\begin{tabular}{|c|c|c|c|c|c|}
\hline $\begin{array}{l}\text { Commodity } \\
\text { Futures }\end{array}$ & Co-efficient & $\begin{array}{l}\text { Commodity } \\
\text { Futures }\end{array}$ & Co-efficient & $\begin{array}{l}\text { Commodity } \\
\text { Futures }\end{array}$ & Co-efficient \\
\hline$\beta_{1 \text { comex/mcx (gold) }}$ & $\begin{array}{l}-0.050 \\
{[-1.377]}\end{array}$ & $\beta_{11 \mathrm{me} / \operatorname{mcx}(\mathrm{copper})}$ & $\begin{array}{l}-0.221 * * \\
{[-5.040]}\end{array}$ & $\beta_{11 \operatorname{me} / \operatorname{mcx}(\text { zinc) }}$ & $\begin{array}{l}-0.260 * * \\
{[-3.787]}\end{array}$ \\
\hline$\beta_{2 \operatorname{mcx} / \text { comex (gold) }}$ & $\begin{array}{l}-0.080 * * \\
{[-2.492]}\end{array}$ & $\beta_{2 \text { mcx }} /$ me(copper) & $\begin{array}{l}-0.108 * * \\
{[-2.084]}\end{array}$ & $\beta_{2 \mathrm{mcx} / \mathrm{me}(\mathrm{zinc})}$ & $\begin{array}{l}-0.198 * * \\
{[-2.516]}\end{array}$ \\
\hline$\beta_{11 \mathrm{me} / \operatorname{mcx}(\text { alum })}$ & $\begin{array}{l}-0.133 * * \\
{[-4.579]}\end{array}$ & $\beta_{1 \text { shfe/mcx(copper) }}$ & $\begin{array}{l}-0.060 * * \\
{[-5.723]}\end{array}$ & $\beta_{1 \text { shfe/mcx(zinc) }}$ & $\begin{array}{l}-0.033 * * \\
{[-3.480]}\end{array}$ \\
\hline$\beta_{2 \mathrm{mcx} / \mathrm{Ime}(\mathrm{alum})}$ & $\begin{array}{l}-0.127^{* *} \\
{[-3.793]}\end{array}$ & $\beta_{2 \text { mcx/shfe(copper) }}$ & $\begin{array}{l}0.004 \\
{[0.246]}\end{array}$ & $\beta_{2 \mathrm{mcx} / \mathrm{shfe}(\mathrm{zinc})}$ & $\begin{array}{l}-0.025 \\
{[-1.625]}\end{array}$ \\
\hline$\beta_{1 \text { comex (silver) }}$ & $\begin{array}{l}-0.028 \\
{[-1.064]}\end{array}$ & $\beta_{1 \text { shfe/lme(copper) }}$ & $\begin{array}{l}-0.066^{* *} \\
{[-5.125]}\end{array}$ & $\beta_{1 \text { shfe/me(zinc) }}$ & $\begin{array}{l}-0.033 * * \\
{[-3.454]}\end{array}$ \\
\hline$\beta_{2 \operatorname{mcx}(\text { silver) }}$ & $\begin{array}{l}-0.050^{* *} \\
{[-2.318]}\end{array}$ & $\beta_{21 \mathrm{me} / \mathrm{shfe}(\mathrm{copper})}$ & $\begin{array}{l}0.014 \\
{[0.868]}\end{array}$ & $\beta_{21 \text { me/shfe(zinc) }}$ & $\begin{array}{l}-0.026 \\
{[-1.610]}\end{array}$ \\
\hline
\end{tabular}

Note: $* *$ denotes the level of significance at $1 \%$ and better.

Table 5 shows the Vector Error Correction Model (VECM) results. With the EC, which is also called the speed of adjustment, coefficient $\beta_{i}$ is exhibiting correct sign. In the case of precious metals, the coefficient EC term is high and significant in case of MCX than COMEX, implying that the futures price of COMEX leads the futures price of MCX. For futures prices of non-precious metals, there are high and significant EC terms for LME and MCX in case of aluminum, with higher magnitude of EC coefficient of LME futures market than in case of MCX, implying that in case of aluminium, MCX leads LME in price discovery process. While in the case of copper, among all three markets, the EC terms are significant, with higher magnitude of EC coefficient in the case of LME followed by MCX and then SHFE. This further implies that it is the SHFE followed by MCX and LME that leads in the price discovery process. Seemingly, for Zinc, it is again LME which has high EC term followed by MCX and SHFE. In other words, SHFE leads MCX and LME in price discovery process. To summarize, we can say that in case of precious metals, futures prices of COMEX assimilate new market information more quickly than MCX. In case of non-precious metals, for aluminium, MCX leads the LME in price discovery process. While, SHFE leads MCX and LME in case of copper and zinc. Based on the results, it can be inferred that except precious metals, futures markets of emerging countries such as China and India have started playing prominent role in price discovery process. The reason could be because these two economies are one of the largest consumer of these metals.

\subsection{Volatility Spillovers}

In this section, we analyze the volatility spillover effects among commodity market platforms. The estimated results are shown in Table 6 (Panels A and B) for precious metals and Tables 7-9 for non-precious metals. The BEKK model is used as the benchmark, and its results are compared with the two restricted correlation models, CCC and DCC. 
Table 6: MGARCH-Precious metal results

Panel A. Gold (COMEX-MCX)

\begin{tabular}{|c|c|c|c|c|c|c|}
\hline & \multicolumn{2}{|l|}{ BEKK } & \multicolumn{2}{|l|}{$\mathrm{CCC}$} & \multicolumn{2}{|l|}{ DCC } \\
\hline & Coeff & t-stat & Coeff & t-stat & Coeff & t-stat \\
\hline$\mu_{1}$ & 0.004 & 0.198 & 0.009 & 0.468 & 0.010 & 0.596 \\
\hline$\mu_{2}$ & 0.007 & 0.349 & -0.001 & -0.062 & 0.007 & 0.429 \\
\hline $\mathrm{C}_{(1,1)}$ & 0.104 & $1.887^{*}$ & 0.011 & 0.657 & 0.015 & 1.255 \\
\hline$c_{(2,1)}$ & 0.010 & 0.212 & - & - & - & - \\
\hline$c_{(2,2)}$ & 0.092 & $2.243^{* *}$ & 0.006 & 1.502 & 0.008 & $2.091^{* *}$ \\
\hline$\alpha_{(1,1)}$ & 0.578 & $7.148^{* *}$ & 0.136 & $2.328^{* *}$ & 0.096 & $2.236 * *$ \\
\hline$\alpha_{(1,2)}$ & 0.000 & -0.004 & -0.059 & -1.350 & 0.005 & 0.165 \\
\hline$\alpha_{(2,1)}$ & -0.354 & $-4.368^{* *}$ & -0.006 & -0.423 & 0.082 & $2.911^{* *}$ \\
\hline$\alpha_{(2,2)}$ & 0.189 & $2.921 * *$ & 0.030 & $2.175^{* *}$ & -0.018 & -0.755 \\
\hline$\beta_{(1,1)}$ & 0.859 & $17.416^{* *}$ & 0.313 & 0.574 & 0.635 & $3.336^{* *}$ \\
\hline$\beta_{(1,2)}$ & 0.050 & 1.135 & 0.671 & 1.137 & 0.289 & 1.562 \\
\hline$\beta_{(2,1)}$ & 0.105 & $1.928^{*}$ & 0.143 & 1.313 & -0.079 & -1.380 \\
\hline$\beta_{(2,2)}$ & 0.933 & $24.246^{* *}$ & 0.843 & $9.012 * *$ & 1.012 & $20.398 * *$ \\
\hline$\rho_{(2,1)}$ & - & - & 0.880 & $124.118 * *$ & - & - \\
\hline$\theta_{(1)}$ & - & - & - & - & 0.108 & $5.714^{* *}$ \\
\hline$\theta_{(2)}$ & - & - & - & - & 0.825 & $30.479 * *$ \\
\hline
\end{tabular}

Panel B. Silver (COMEX-MCX)

\begin{tabular}{|c|c|c|c|c|c|c|}
\hline & \multicolumn{2}{|l|}{ BEKK } & \multicolumn{2}{|l|}{$\mathrm{CCC}$} & \multicolumn{2}{|l|}{ DCC } \\
\hline & Coeff & t-stat & Coeff & t-stat & Coeff & t-stat \\
\hline$\mu_{1}$ & 0.034 & 1.538 & 0.019 & 0.859 & 0.020 & 0.994 \\
\hline$\mu_{2}$ & 0.031 & 1.522 & 0.017 & 0.801 & 0.018 & 1.004 \\
\hline $\mathrm{C}_{(1,1)}$ & 0.267 & $4.671^{* *}$ & 0.032 & 1.758 & 0.027 & $2.073 *$ \\
\hline $\mathrm{C}_{(2,1)}$ & 0.164 & $3.257^{* *}$ & - & - & - & - \\
\hline $\mathrm{C}_{(2,2)}$ & 0.000 & 0.000 & 0.019 & 1.297 & 0.022 & 1.488 \\
\hline$\alpha_{(1,1)}$ & 0.107 & 0.623 & 0.127 & $4.949 * *$ & 0.084 & $1.959 *$ \\
\hline$\alpha_{(1,2)}$ & -0.316 & -1.545 & 0.028 & 1.010 & 0.072 & 1.006 \\
\hline$\alpha_{(2,1)}$ & 0.290 & 1.293 & -0.084 & -0.938 & -0.031 & -0.284 \\
\hline$\alpha_{(2,2)}$ & 0.703 & $4.143 * *$ & 0.301 & $2.626 * *$ & 0.238 & $2.182 * *$ \\
\hline$\beta_{(1,1)}$ & 1.259 & $8.422 * *$ & 0.869 & $5.364 * *$ & 0.978 & $3.886 * *$ \\
\hline$\beta_{(1,2)}$ & 0.417 & $3.107^{* *}$ & -0.045 & -0.291 & -0.179 & -0.600 \\
\hline$\beta_{(2,1)}$ & -0.458 & $-2.615^{* *}$ & 0.519 & $2.009 * *$ & 0.443 & $2.408^{* *}$ \\
\hline$\beta_{(2,2)}$ & 0.490 & 3.414 & 0.308 & 1.214 & 0.377 & $2.192^{* *}$ \\
\hline$\rho_{(2,1)}$ & - & - & 0.903 & $101.635^{* *}$ & - & - \\
\hline$\theta_{(1)}$ & - & - & - & - & 0.032 & 0.675 \\
\hline$\theta_{(2)}$ & - & - & - & - & 0.646 & 1.399 \\
\hline
\end{tabular}

Note: Models estimated using QMLE with robust (heteroskedasticity/misspecification) standard errors. In the variance equations, $\mathrm{c}$ denotes the constant terms, $\alpha$ denotes the ARCH terms and $\beta$ denotes the GARCH terms. The coefficient $\alpha_{12}$ for example represents the short-term volatility spillover from COMEX to MCX for Gold \& Silver in Panels A \& B, respectively. While, $\beta_{12}$ represents the long-term volatility spillover from COMEX to MCX for both panels and is interpreted in the same manner as above. * and $* *$ denote level of significance at $5 \%$ and above and $1 \%$ and better, respectively. 
The results of BEKK model for precious metals, as shown in Table 6 (Panels A and B), indicate several instances of significant volatility spillovers. For both the short and long term, in the case of gold, the results confirm unidirectional volatility spillover from MCX to COMEX, implying that the former is a more dominant trading platform compared to the latter. Similarly, for silver (see Table 6, Panel B), there is no significant volatility spillover between both markets in the short run, while, in the long term, there is bilateral volatility spillovers between the COMEX and MCX futures markets, with stronger volatility spillover moving from the latter to the former. In sum, based on price discovery and volatility spillover results, MCX seems to be more dominant platform vis-à-vis COMEX for precious metals. This is in contrast with price discovery results where COMEX leads MCX in price discovery process. In the case of non-precious metals, starting with aluminum, the results between MCX and LME (see Table 7, Panel A) indicate bidirectional volatility spillover in the short and long terms, with stronger volatility moving from MCX to LME. Due to the absence of cointegration, volatility spillovers have not been studied for SHFE-MCX and SHFE-LME combinations.

Table 7: MGARCH-Aluminum results

Panel A: MCX-LME

\begin{tabular}{|c|c|c|c|c|c|c|}
\hline \multirow[t]{3}{*}{ Variable } & \multicolumn{6}{|c|}{ MCX and LME } \\
\hline & \multicolumn{2}{|l|}{ BEKK } & \multicolumn{2}{|l|}{$\mathrm{CCC}$} & \multicolumn{2}{|l|}{ DCC } \\
\hline & Coeff & t-stat & Coeff & t-stat & Coeff & t-stat \\
\hline$\mu_{1}$ & -0.005 & -0.275 & -0.015 & -0.670 & -0.008 & -0.356 \\
\hline$\mu_{2}$ & 0.015 & 0.732 & 0.005 & 0.209 & 0.021 & 0.890 \\
\hline $\mathrm{c}_{(1,1)}$ & 0.223 & $5.014^{* *}$ & -0.044 & -0.663 & 0.010 & 1.366 \\
\hline $\mathrm{c}_{(2,1)}$ & 0.144 & $4.382 * *$ & - & - & - & - \\
\hline $\mathrm{c}_{(2,2)}$ & 0.000 & 0.000 & 0.049 & 1.704 & 0.011 & 0.874 \\
\hline$\alpha_{(1,1)}$ & 0.099 & 1.589 & 0.137 & $2.291 * *$ & 0.002 & 0.253 \\
\hline$\alpha_{(1,2)}$ & -0.222 & $-4.839 * *$ & -0.066 & -0.966 & 0.062 & $4.262 * *$ \\
\hline$\alpha_{(2,1)}$ & 0.162 & $3.391 * *$ & -0.035 & -1.057 & 0.020 & 1.079 \\
\hline$\alpha_{(2,2)}$ & 0.314 & $6.656^{* *}$ & 0.069 & $2.566^{* *}$ & 0.024 & 1.260 \\
\hline$\beta_{(1,1)}$ & 1.095 & $39.974 * *$ & -0.411 & -1.511 & 1.214 & $5.632 * *$ \\
\hline$\beta_{(1,2)}$ & 0.266 & $8.430 * *$ & 2.065 & $4.820 * *$ & -0.416 & -1.353 \\
\hline$\beta_{(2,1)}$ & -0.251 & $-9.236^{* *}$ & 1.334 & 1.015 & 0.595 & 1.264 \\
\hline$\beta_{(2,2)}$ & 0.765 & $40.324 * *$ & 0.040 & 0.053 & 0.591 & $2.219 * *$ \\
\hline$\rho_{(2,1)}$ & - & - & 0.657 & $22.037 * *$ & - & - \\
\hline$\theta_{(1)}$ & - & - & - & - & 0.060 & $1.927^{*}$ \\
\hline$\theta_{(2)}$ & - & - & - & - & 0.188 & 0.319 \\
\hline
\end{tabular}

In the case of copper (see Table 8, Panels A to C), in the short and long term, there is a bidirectional volatility spillover between MCX and LME, with marginally stronger volatility spillovers moving from LME to MCX in the short term, while in the long term, there is stronger volatility spillover moving from MCX to LME (see Table 9, Panel A). Between MCX and SHFE and between SHFE and LME, there are no short- or long-term volatility 
spillovers using the BEKK model. This is in contrast with the results of the CCC and DCC models, which indicate unidirectional volatility spillovers moving from MCX to SHFE, and bilateral volatility spillovers between SHFE and LME, which are stronger from LME to SHFE in the short term and SHFE to LME in the long term. The results imply that volatility in MCX is having strong bearing on the SHFE futures market, while there is stronger volatility transmission from LME to SHFE (see Panels B and C).

Table 8: MGARCH-Copper results

Panel A: $M C X-L M E$

\begin{tabular}{|c|c|c|c|c|c|c|}
\hline & BEKK & & CCC & & DCC & \\
\hline & Coeff & t-stat & Coeff & t-stat & Coeff & t-stat \\
\hline$\mu_{1}$ & 0.029 & 1.584 & 0.036 & 1.834 & 0.038 & $1.909 *$ \\
\hline$\mu_{2}$ & 0.036 & $1.929 *$ & 0.036 & 1.718 & 0.042 & $2.187 * *$ \\
\hline $\mathrm{c}_{(1,1)}$ & 0.171 & 1.879 & 0.053 & $2.104 * *$ & 0.047 & $3.079 * *$ \\
\hline $\mathrm{c}_{(2,1)}$ & 0.024 & 0.170 & - & - & - & - \\
\hline $\mathrm{c}_{(2,2)}$ & 0.037 & 0.471 & 0.003 & 0.099 & 0.024 & 1.782 \\
\hline$\alpha_{(1,1)}$ & 0.103 & $2.052 * *$ & 0.149 & $4.027 * *$ & 0.131 & $3.127 * *$ \\
\hline$\alpha_{(1,2)}$ & -0.213 & $-4.844 * *$ & -0.002 & -0.049 & 0.008 & 0.163 \\
\hline$\alpha_{(2,1)}$ & 0.219 & $4.627 * *$ & -0.053 & -1.496 & -0.012 & -0.302 \\
\hline$\alpha_{(2,2)}$ & 0.290 & $5.729 * *$ & 0.106 & $4.007 * *$ & 0.090 & $3.626 * *$ \\
\hline$\beta_{(1,1)}$ & 1.104 & $34.451 * *$ & 0.423 & $2.522 * *$ & 0.709 & $6.058 * *$ \\
\hline$\beta_{(1,2)}$ & 0.321 & $6.236^{* *}$ & 0.551 & $2.232 * *$ & 0.164 & 1.119 \\
\hline$\beta_{(2,1)}$ & -0.262 & $-13.298 * *$ & 0.930 & 1.773 & 0.350 & 1.391 \\
\hline$\beta_{(2,2)}$ & 0.728 & $16.434 * *$ & 0.290 & 0.896 & 0.655 & $4.076^{* *}$ \\
\hline$\rho_{(2,1)}$ & - & - & 0.695 & $33.937 * *$ & - & - \\
\hline$\theta_{(1)}$ & - & - & - & - & 0.039 & 1.344 \\
\hline$\theta_{(2)}$ & - & - & - & - & 0.905 & $11.180 * *$ \\
\hline
\end{tabular}

Panel B: MCX-SHFE

\begin{tabular}{lcccccc}
\hline & BEKK & & CCC & & DCC & \\
\cline { 2 - 6 } & Coeff & t-stat & Coeff & t-stat & Coeff & t-stat \\
\hline$\mu_{1}$ & 0.030 & 1.395 & 0.028 & 1.249 & 0.027 & 1.226 \\
$\mu_{2}$ & 0.014 & 0.653 & 0.015 & 0.841 & 0.014 & 0.766 \\
$\mathrm{c}_{(1,1)}$ & 0.198 & $4.765^{* *}$ & 0.064 & $2.232^{* *}$ & 0.064 & $2.761^{* *}$ \\
$\mathrm{c}_{(2,1)}$ & 0.015 & 0.149 & - & - & - & - \\
$\mathrm{c}_{(2,2)}$ & 0.149 & $2.687^{* *}$ & -0.014 & -0.359 & -0.013 & -0.330 \\
$\alpha_{(1,1)}$ & 0.186 & 1.601 & 0.149 & $4.560^{* *}$ & 0.150 & $4.468^{* *}$ \\
$\alpha_{(1,2)}$ & -0.213 & -1.398 & -0.055 & $-2.161^{* *}$ & -0.058 & $-2.023^{* *}$ \\
$\alpha_{(2,1)}$ & 0.129 & 1.089 & 0.016 & 0.590 & 0.015 & 0.632 \\
$\alpha_{(2,2)}$ & 0.370 & $4.836^{* *}$ & 0.125 & $4.278^{* *}$ & 0.126 & $4.744^{* *}$ \\
$\beta_{(1,1)}$ & 0.959 & $35.689 * *$ & 0.456 & $2.911^{* *}$ & 0.460 & $3.381^{* *}$ \\
$\beta_{(1,2)}$ & 0.069 & 0.755 & 0.856 & $2.425^{* *}$ & 0.850 & $2.750^{* *}$ \\
$\beta_{(2,1)}$ & -0.039 & -0.539 & 1.324 & 1.697 & 1.318 & 1.733 \\
$\beta_{(2,2)}$ & 0.901 & $13.870^{* *}$ & 0.349 & 1.191 & 0.352 & 1.288 \\
$\rho_{(2,1)}$ & - & - & 0.416 & $19.982^{* *}$ & - & - \\
$\theta_{(1)}$ & - & - & - & - & 0.000 & 0.228 \\
$\theta_{(2)}$ & - & - & - & - & 0.925 & $17.018^{* *}$ \\
\hline & & & 164 & & & www.macrothink.org/rae
\end{tabular}


Panel C: SHFE- LME

\begin{tabular}{|c|c|c|c|c|c|c|}
\hline & \multicolumn{2}{|l|}{ BEKK } & \multicolumn{2}{|l|}{$\mathrm{CCC}$} & \multicolumn{2}{|l|}{ DCC } \\
\hline & Coeff & t-stat & Coeff & t-stat & Coeff & t-stat \\
\hline$\mu_{1}$ & 0.009 & 0.437 & 0.003 & 0.190 & 0.002 & 0.133 \\
\hline$\mu_{2}$ & 0.021 & 1.119 & 0.015 & 0.940 & 0.016 & 0.877 \\
\hline $\mathrm{C}_{(1,1)}$ & 0.151 & $3.693^{* *}$ & -0.009 & -0.267 & -0.006 & -0.314 \\
\hline$C_{(2,1)}$ & 0.041 & 0.862 & - & - & - & - \\
\hline$C_{(2,2)}$ & 0.117 & $5.170 * *$ & 0.042 & $1.986 * *$ & 0.036 & $2.076 * *$ \\
\hline$\alpha_{(1,1)}$ & 0.410 & $5.522 * *$ & 0.159 & $4.604 * *$ & 0.159 & $5.069 * *$ \\
\hline$\alpha_{(1,2)}$ & 0.031 & 0.389 & -0.038 & -1.518 & -0.042 & $-2.252 * *$ \\
\hline$\alpha_{(2,1)}$ & -0.180 & -1.725 & -0.106 & $-2.785^{* *}$ & -0.125 & $-3.187^{* *}$ \\
\hline$\alpha_{(2,2)}$ & 0.181 & $2.726 * *$ & 0.143 & $4.870 * *$ & 0.152 & $5.258 * *$ \\
\hline$\beta_{(1,1)}$ & 0.885 & $20.441 * *$ & 0.373 & 1.852 & 0.401 & $4.724 * *$ \\
\hline$\beta_{(1,2)}$ & -0.034 & -1.185 & 0.810 & $2.104^{* *}$ & 0.786 & $4.105^{* *}$ \\
\hline$\beta_{(2,1)}$ & 0.079 & 1.716 & 0.663 & $2.813^{* *}$ & 0.665 & $7.037 * *$ \\
\hline$\beta_{(2,2)}$ & 0.993 & $49.499 * *$ & 0.458 & $3.385^{* *}$ & 0.480 & $6.766 * *$ \\
\hline$\rho_{(2,1)}$ & - & - & 0.641 & $42.216^{* *}$ & - & - \\
\hline$\theta_{(1)}$ & - & - & - & - & 0.027 & $2.095^{* *}$ \\
\hline$\theta_{(2)}$ & - & - & - & - & 0.387 & $2.037^{* *}$ \\
\hline
\end{tabular}

Note: Models estimated using QMLE with robust (heteroskedasticity/misspecification) standard errors. In the variance equations, $\mathrm{c}$ denotes the constant terms, $\alpha$ denotes the ARCH terms and $\beta$ denotes the GARCH terms. The coefficient $\alpha_{12}$ for example represents the short-term volatility spillover from MCX to LME in Panel A, MCX to SHFE in Panel B and SHFE to LME in Panel C, respectively, while, $\beta_{12}$ represents the long-term volatility spillover in the same manner as mentioned above. $*$ and $* *$ denote level of significance at $5 \%$ and above and $1 \%$ and better, respectively.

Table 9: MGARCH-Zinc results

Panel A: MCX-LME

\begin{tabular}{|c|c|c|c|c|c|c|}
\hline & \multicolumn{2}{|l|}{ BEKK } & \multicolumn{2}{|l|}{ CCC } & \multicolumn{2}{|l|}{ DCC } \\
\hline & Coeff & t-stat & Coeff & t-stat & Coeff & t-stat \\
\hline$\mu_{1}$ & 0.021 & 0.694 & 0.032 & 1.427 & 0.028 & 1.105 \\
\hline$\mu_{2}$ & 0.015 & 0.572 & 0.028 & 1.179 & 0.030 & 1.005 \\
\hline $\mathrm{c}_{(1,1)}$ & 0.719 & 1.801 & 0.023 & 0.830 & 0.013 & 0.482 \\
\hline $\mathrm{c}_{(2,1)}$ & 0.577 & 1.672 & - & - & - & - \\
\hline $\mathrm{c}_{(2,2)}$ & 0.000 & 0.001 & -0.049 & $-2.134 * *$ & -0.049 & $-2.201 * *$ \\
\hline$\alpha_{(1,1)}$ & -0.381 & $-2.088 * *$ & 0.030 & 0.561 & 0.021 & 0.698 \\
\hline$\alpha_{(1,2)}$ & -0.114 & -0.548 & -0.036 & -0.658 & -0.032 & -0.647 \\
\hline$\alpha_{(2,1)}$ & 0.487 & $2.193 * *$ & 0.076 & 1.366 & 0.055 & 1.136 \\
\hline$\alpha_{(2,2)}$ & 0.389 & 1.651 & 0.046 & 0.747 & 0.060 & 1.345 \\
\hline$\beta_{(1,1)}$ & 0.652 & 1.556 & 0.615 & $1.826^{*}$ & 0.702 & 1.723 \\
\hline$\beta_{(1,2)}$ & -0.238 & -0.727 & 0.469 & 1.117 & 0.383 & 0.741 \\
\hline$\beta_{(2,1)}$ & -0.049 & -0.237 & 0.969 & $4.486^{* *}$ & 1.108 & $4.286^{* *}$ \\
\hline$\beta_{(2,2)}$ & 0.918 & $5.434 * *$ & 0.227 & 1.467 & 0.136 & 0.766 \\
\hline$\rho_{(2,1)}$ & - & - & 0.758 & $55.437 * *$ & - & - \\
\hline$\theta_{(1)}$ & - & - & - & - & 0.011 & 0.462 \\
\hline$\theta_{(2)}$ & - & - & - & - & 0.821 & $2.067 * *$ \\
\hline
\end{tabular}


Panel B: MCX-SHFE

\begin{tabular}{|c|c|c|c|c|c|c|}
\hline & \multicolumn{2}{|l|}{ BEKK } & \multicolumn{2}{|l|}{$\mathrm{CCC}$} & \multicolumn{2}{|l|}{ DCC } \\
\hline & Coeff & t-stat & Coeff & t-stat & Coeff & t-stat \\
\hline$\mu_{1}$ & 0.024 & 0.773 & 0.022 & 0.851 & 0.019 & 0.813 \\
\hline$\mu_{2}$ & 0.027 & 0.979 & 0.008 & 0.332 & 0.011 & 0.485 \\
\hline$C_{(1,1)}$ & 0.119 & $2.676 * *$ & 0.113 & $8.879 * *$ & 0.065 & $2.548 * *$ \\
\hline$C_{(2,1)}$ & 0.068 & 1.588 & - & - & - & - \\
\hline $\mathrm{C}_{(2,2)}$ & 0.000 & -0.002 & -0.149 & $-10.081 * *$ & -0.109 & $-3.832 * *$ \\
\hline$\alpha_{(1,1)}$ & 0.139 & $1.827^{*}$ & 0.095 & $4.411^{* *}$ & 0.089 & $3.579 * *$ \\
\hline$\alpha_{(1,2)}$ & 0.223 & $2.520 * *$ & 0.018 & 0.685 & -0.085 & $-2.884 * *$ \\
\hline$\alpha_{(2,1)}$ & -0.148 & $-4.055^{* *}$ & -0.021 & -0.551 & -0.032 & -0.966 \\
\hline$\alpha_{(2,2)}$ & 0.153 & 1.950* & 0.084 & $4.283^{* *}$ & 0.106 & $4.162 * *$ \\
\hline$\beta_{(1,1)}$ & 0.956 & $102.201^{* *}$ & 0.038 & $2.099 * *$ & 0.370 & 1.693 \\
\hline$\beta_{(1,2)}$ & -0.129 & $-4.657^{* *}$ & 15.547 & $67.199 * *$ & 6.292 & $2.384 * *$ \\
\hline$\beta_{(2,1)}$ & 0.126 & $3.795 * *$ & 36.332 & $30.024 * *$ & 17.102 & $3.497 * *$ \\
\hline$\beta_{(2,2)}$ & 0.960 & $69.165^{* *}$ & -0.725 & $-7.769 * *$ & -0.319 & -0.857 \\
\hline$\rho_{(2,1)}$ & - & - & 0.049 & $62.881^{* *}$ & - & - \\
\hline$\theta_{(1)}$ & - & - & - & - & 0.006 & $3.088^{* *}$ \\
\hline$\theta_{(2)}$ & - & - & - & - & 0.000 & 0.059 \\
\hline
\end{tabular}

Panel C: SHFE-LME

\begin{tabular}{|c|c|c|c|c|c|c|}
\hline & \multicolumn{2}{|l|}{ BEKK } & \multicolumn{2}{|l|}{$\mathrm{CCC}$} & \multicolumn{2}{|l|}{ DCC } \\
\hline & Coeff & t-stat & Coeff & t-stat & Coeff & t-stat \\
\hline$\mu_{1}$ & 0.024 & 0.805 & 0.034 & 1.418 & 0.030 & 1.076 \\
\hline$\mu_{2}$ & 0.033 & 1.109 & 0.025 & 0.928 & 0.020 & 0.841 \\
\hline$c_{(1,1)}$ & 0.246 & $3.926 * *$ & 0.104 & 1.728 & 0.057 & 0.951 \\
\hline$C_{(2,1)}$ & -0.050 & -0.721 & - & - & - & - \\
\hline$c_{(2,2)}$ & 0.000 & 0.000 & -0.128 & -1.380 & -0.102 & -0.978 \\
\hline$\alpha_{(1,1)}$ & 0.190 & $2.488^{* *}$ & 0.092 & $3.625^{* *}$ & 0.080 & $2.755^{* *}$ \\
\hline$\alpha_{(1,2)}$ & 0.262 & $4.758^{* *}$ & 0.007 & 0.233 & -0.082 & $-2.409 * *$ \\
\hline$\alpha_{(2,1)}$ & -0.111 & -1.804 & -0.032 & -0.804 & -0.047 & -1.457 \\
\hline$\alpha_{(2,2)}$ & 0.169 & $3.938 * *$ & 0.092 & $3.488^{* *}$ & 0.111 & $4.209 * *$ \\
\hline$\beta_{(1,1)}$ & 0.883 & $29.352^{* *}$ & 0.140 & 0.740 & 0.429 & $1.883^{*}$ \\
\hline$\beta_{(1,2)}$ & 0.434 & $15.187^{* *}$ & 10.684 & $3.058^{* *}$ & 5.213 & $2.094^{* *}$ \\
\hline$\beta_{(2,1)}$ & -0.451 & $-17.402 * *$ & 25.758 & $3.360 * *$ & 16.969 & $3.572 * *$ \\
\hline$\beta_{(2,2)}$ & 0.794 & $32.143^{* *}$ & -0.565 & -1.749 & -0.446 & -1.349 \\
\hline$\rho_{(2,1)}$ & & & 0.063 & $14.000 * *$ & & \\
\hline$\theta_{(1)}$ & & & & & 0.006 & $3.231 * *$ \\
\hline$\theta_{(2)}$ & & & & & 0.000 & 1.670 \\
\hline
\end{tabular}

Note: Models estimated using QMLE with robust (heteroskedasticity/misspecification) standard errors. In the variance equations, $\mathrm{c}$ denotes the constant terms, $\alpha$ denotes the $\mathrm{ARCH}$ terms and $\beta$ denotes the GARCH terms. The coefficient $\alpha_{12}$ for example represents the short-term volatility spillover from MCX to LME in Panel A, MCX to SHFE in Panel B and SHFE to LME in Panel C, respectively, while, $\beta_{12}$ represents the long-term volatility spillover in the same manner as mentioned above. $*$ and $* *$ denote level of significance at $5 \%$ and above and $1 \%$ and better, respectively. 
Lastly, in the case of zinc (see Table 9, Panels A to C), between MCX and LME there is unilateral volatility spillover moving from LME to MCX. In the long term, the BEKK results indicate no evidence of volatility spillovers between either trading platforms. This is in contrast to the CCC and DCC models, which indicate unidirectional volatility spillover from LME to MCX (see Panel A). Similarly, between MCX and SHFE there are bilateral volatility spillovers moving strongly from MCX to SHFE in the short as well as long term, implying that there is stronger volatility transmission from MCX to SHFE (see Panel B). Between SHFE and LME, there is unidirectional volatility spillover from SHFE to LME. In the long term, there is bilateral volatility spillover moving strongly from LME to SHFE (see Panel C).

Table 10: Diagnostic tests for standardized residuals

\begin{tabular}{|c|c|c|c|c|c|c|}
\hline & \multicolumn{2}{|c|}{ BEKK } & \multicolumn{2}{|l|}{ CCC } & \multicolumn{2}{|l|}{ DCC } \\
\hline & $Q_{(20)}$ & $\mathrm{Q}_{\mathrm{sqr}(20)}$ & $\mathrm{Q}_{(20)}$ & $\mathrm{Q}_{\mathrm{sqr}(20)}$ & $\mathrm{Q}_{(20)}$ & $Q_{\text {sqr }(20)}$ \\
\hline \multirow[t]{2}{*}{ Gold (COMEX-MCX) } & 23.245 & 18.539 & 24.982 & 19.578 & 22.501 & 19.003 \\
\hline & {$[0.277]$} & {$[0.552]$} & {$[0.202]$} & {$[0.485]$} & {$[0.314]$} & {$[0.522]$} \\
\hline \multirow[t]{2}{*}{ Silver (COMEX-MCX) } & 15.258 & 22.179 & 13.646 & 21.256 & 13.864 & 21.447 \\
\hline & {$[0.762]$} & {$[0.331]$} & {$[0.848]$} & {$[0.382]$} & {$[0.837]$} & [0.371] \\
\hline \multirow[t]{2}{*}{ Aluminium (MCX-LME) } & 26.470 & 9.017 & 25.598 & 9.486 & 25.678 & 9.515 \\
\hline & {$[0.151]$} & {$[0.983]$} & {$[0.180]$} & {$[0.977]$} & {$[0.177]$} & [0.976] \\
\hline \multirow[t]{2}{*}{ Copper (MCX-LME) } & 18.751 & 21.473 & 19.393 & 20.415 & 18.214 & 19.565 \\
\hline & {$[0.538]$} & {$[0.370]$} & [0.497] & {$[0.432]$} & {$[0.573]$} & {$[0.485]$} \\
\hline \multirow[t]{2}{*}{ Copper (MCX-SHFE) } & 11.347 & 13.683 & 10.608 & 14.923] & 10.416 & 14.402 \\
\hline & [0.937] & {$[0.846]$} & {$[0.956]$} & {$[0.781]$} & [0.960] & [0.810] \\
\hline \multirow[t]{2}{*}{ Copper (SHFE-LME) } & 18.711 & 18.217 & 18.007 & 19.754 & 17.893 & 19.815 \\
\hline & {$[0.541]$} & {$[0.573]$} & {$[0.587]$} & {$[0.473]$} & {$[0.595]$} & {$[0.470]$} \\
\hline \multirow[t]{2}{*}{ Zinc (MCX-LME) } & 15.716 & 16.171 & 13.434 & 15.315 & 12.917 & 15.089 \\
\hline & {$[0.734]$} & {$[0.706]$} & {$[0.858]$} & {$[0.758]$} & {$[0.881]$} & {$[0.771]$} \\
\hline \multirow[t]{2}{*}{ Zinc (MCX-SHFE) } & 10.815 & 14.055 & 11.084 & 13.986 & 10.464 & 13.307 \\
\hline & {$[0.951]$} & {$[0.828]$} & {$[0.944]$} & {$[0.831]$} & {$[0.959]$} & {$[0.864]$} \\
\hline \multirow[t]{2}{*}{ Zinc (SHFE-LME) } & 13.227 & 19.001 & 13.700 & 20.268 & 13.833 & 20.396 \\
\hline & {$[0.868]$} & {$[0.522]$} & {$[0.845]$} & {$[0.441]$} & {$[0.839]$} & [0.433] \\
\hline
\end{tabular}

Note: values in parentheses are p-values.

The results of the CCC model for sample commodities indicate highly positive correlations with a significance level of $1 \%$ and better. In case of precious metals (gold and silver) (see Table 6, Panels A and B), the correlation coefficients between COMEX and MCX $\left(\rho_{21}\right)$ are 0.88 (gold) and 0.90 (silver). Similarly, for non-precious metals, in the case of aluminum, the magnitude of correlation between MCX and LME $\left(\rho_{21}\right)$ is 0.65 (see Table 7, Panel A). In the case of copper, the highest correlation is between $\operatorname{MCX}$ and $\operatorname{LME}\left(\rho_{21}\right), 0.69$, followed by SHFE and LME $\left(\rho_{21}\right)$ at 0.64 , and MCX and SHFE at 0.41 (see Table 8, Panels A, B, and C). For zinc (see Table 9, Panels A, B, and C), the strongest correlation is between MCX and $\operatorname{LME}\left(\rho_{21}\right), 0.75$, followed by SHFE and $\operatorname{LME}\left(\rho_{21}\right)$ at 0.06 , and the lowest correlation is observed in the case of MCX and SHFE at 0.04. It may be noted that, among all commodities, 
the highest correlations are appeared to be in the case of gold and silver, implying that the trading platforms for bullion are more synchronized in terms of trade facilitation and information transmission compared to trading platforms for metals. Hence, precious metal trading exhibits stronger information transmission and, therefore, a relatively greater international character.

The results of the DCC model indicate that the estimated coefficients on $\theta_{1}$ and $\theta_{2}$ for examined commodities are positive, but the level of significance varies. These estimated coefficients sum to a value that is less than 1, implying that the dynamic conditional correlations of all commodities are mean-reverting. In Table 10, which shows the diagnostic tests for the standardized residuals and their squared terms, we find no evidence of significant serial correlation at the $1 \%$ or even $5 \%$ level of significance and better. The results indicate no evidence of autocorrelation, even in the squared standardized residuals.

\section{Summary and Conclusion}

This study examines the process of information transmission in futures prices of bullion and metals between India, represented by MCX, and its global counterparts, such as COMEX, LME, and SHFE. The sample period of the study is from 2005 to 2012 (through April). We identify structural breaks for all sample futures price series. These structural breaks highlight the boom period of 2006, the U.S. subprime crisis of 2008, and the Eurozone crisis of 20102011. The price discovery results confirm that there is a long-term equilibrium relationship among the futures prices of examined trading platforms, even after accounting for the structural break in each commodity series, implying that there is informational efficiency across sample markets. Long-term equilibrium relationships, however, are not confirmed for MCX-SHFE and LME-SHFE in the case of aluminum, implying an absence of price discovery for these cases. For precious metals (gold and silver), if there is any disequilibrium in the short run, MCX makes faster speed of adjustment than COMEX to restore the long-run equilibrium. In other words, futures market of COMEX leads the MCX in price discovery process. MCX impounds new market information quicker than LME in case of aluminum. For copper and zinc, it is the SHFE which leads MCX and LME.

The results of volatility spillovers under the MGARCH framework indicate that there exist both short-term as well as long-term volatility spillovers between sample markets in general. However, in the case of gold, there is univariate volatility spillover from MCX to COMEX, both in the short and long terms. No short-term spillover effects are observed in case of silver; in the long term, however, there is bivariate spillover moving stronger from MCX to COMEX. The results imply that while innovations in each market impact volatility, in the other market, MCX seems to play a more dominant role in the process. For aluminum, copper, and zinc, unilateral short-run volatility spillovers are observed from LME to MCX, while bilateral spillovers are observed in the long term, with more dominant role for MCX, vis-à-vis LME, for the first two metals. Long-term volatility spillover effects seem to be absent in the case of zinc. Both MCX and LME play more important role in information 
transmission related to volatility spillover than SHFE. The volatility spillover results provided by the BEKK model exhibits some contradiction with the other two restricted models, CCC and DCC, for copper and zinc.

Our empirical results have strong economic implications for market players, regulators as well as acedamicians working on international financial integration literature. For precious metals, while COMEX tends to play lead role in price discovery process, the volatility related information transmission in the long-run seems to be stronger from MCX to COMEX. Thus, in contrast to Kumar and Pandey (2011), COMEX does not appear to be a fully dominant platform in overall information transmission process. In other words, MCX an emerging market platform may not qualify as a pure satellite market. For non-precious metals, emerging market platforms in China (SHFE) and India (MCX) appear to be more dominant than the mature market platform both in price discovery as well as volatility spillover process. Thus, emerging market platforms have achieved their due importance given the level of high demand for these metals in the fast growing manufacuturing process. Recent global economic crisis has impacted all economies but the western economies have been more worst compared to their emerging counterparts. Hence, the center of gravirty of world economy has gradually been shifting from west to east and there is a likelihood that the emerging market platforms may perform leadership role in information transmission for all other commodities including precious metals in near future.

Our results highlight the role of emerging commodity market platforms in the international information transmission process. Hence, policy makers in emerging markets such as India should facilitate necessary institutional and fiscal infrastrcuture, as well as regulatory reforms, so that their commodity market trading platforms can achieve greater liquidity and efficiency to achieve a relatively more dominant position in international information transmission process.

\section{Acknowledgment}

The authors would like to thank Professor Emeritus Klaus Spremann for his useful suggestions. Any errors or omission are solely ours.

\section{References}

Baele, L. (2005). Volatility spillover effects in European equity markets: Evidence from a regime switching Model. Journal of Financial and Quantitative Analysis, 40(2), 373401. http://dx.doi.org/10.1017/S0022109000002350

Bai, J., \& Perron, P. (1998). Estimating and testing linear models with multiple structural changes. Econometrica, 66(1), 47-78. http://dx.doi.org/10.2307/2998540

Bai, J., \& Perron, P. (2003a). Computation and analysis of multiple structural change models. Journal of Applied Econometrics, 18(1), 1-22. http://dx.doi.org/10.1002/jae.659 
Bai, J., \& Perron, P. (2003b). Critical values for multiple structural change tests. Econometrics Journal, 6(1), 72-78. http://dx.doi.org/10.1111/1368-423X.00102

Bekaert, G., \& Harvey, C. R. (1997). Emerging equity market volatility. Journal of Financial Economics, 43(1), 29-77. http://dx.doi.org/10.1016/S0304-405X(96)00889-6

Bollerslev, T. (1990). Modeling the coherence in short-run nominal exchange rates: A multivariate generalized ARCH model. Review of Economics and Statistics, 72(3), 498506. http://dx.doi.org/10.2307/2109358

Booth, G. G., Brockman, P., \& Tse, Y. (1998). The relationship between US and Canadian wheat futures. Applied Financial Economics, 8(1), 73-80. http://dx.doi.org/10.1080/096031098333276

Booth, G. G., \& Ciner, C. (1997). International transmission of information in corn futures markets. Journal of Multinational Financial Management, 7(3), 175-187. http://dx.doi.org/10.1016/S1042-444X(97)00012-1

Booth, G. G., Lee, H. T., \& Tse, Y. (1996). International linkages in the Nikkei stock index futures markets. Pacific Basin Finance Journal, 4(1), 59-76. http://dx.doi.org/10.1016/0927-538X(95)00023-E

Booth, G. G., Martikainen, T., \& Tse, Y. (1997). Price and volatility spillovers in Scandinavian stock markets. Journal of Banking and Finance, 21(6), 811-823. http://dx.doi.org/10.1016/S0378-4266(97)00006-X

Carter, C. A. (1989). Arbitrage opportunities between thin and liquid futures markets. Journal of Futures Markets, 9(4), 347-353. http://dx.doi.org/10.1002/fut.3990090408

Chan, K., Chan, K. C., \& Karolyi, G. A. (1991). Intraday volatility in the stock index and stock index futures markets. Review of Financial Studies, 4(4), 657-684. http://dx.doi.org/10.1093/rfs/4.4.657

Chan, K. C., Fung, H. G., \& Leung, W. K. (2004). Daily volatility behavior in the Chinese futures markets. Journal of International Financial Markets, Institutions and Money, 14(5), 491-505. http://dx.doi.org/10.1016/j.intfin.2004.01.002

Christofi, A., \& Pericli, A. (1999). Correlation in price changes and volatility of major Latin American stock markets. Journal of Multinational Financial Management, 9(1), 79-93. http://dx.doi.org/10.1016/S1042-444X(98)00047-4

Commodity Insight Year Book., (2011). Retrieved May 10, 2012, from http://www.mcxindia.com /knowledgehub/commoditybook/commoditybook.htm

Cook, S. (2006). Are stock prices and economic activity co-integrated? Evidence from the United States, 1950-2005. Annals of Financial Economics, 2, 2-16.

Dey, K., \& Maitra, D. (2011). Price discovery and market efficiency revisited: Anecdotes from the Indian commodity futures markets. Commodity Vision, 4(4), 22-34. 
Ding, D. K., Harris, F. H., Lau, S. T., \& McInish, T. H. (1999). An investigation of price discovery in informationally-linked markets: Equity trading in Malaysia and Singapore. Journal of Multinational Financial Management, 9(3-4), 317-329. http://dx.doi.org/10.1016/S1042-444X(99)00005-5

Du, X., Yu, L. C., \& Hayes, D. J. (2011). Speculation and volatility spillover in the crude oil and agricultural commodity markets: A Bayesian analysis. Energy Economics, 33(3), 497-503. http://dx.doi.org/10.1016/j.eneco.2010.12.015

Engle, R. F. (2002). Dynamic conditional correlation: A simple class of multivariate generalized autoregressive conditional heteroskedasticity models. Journal of Business \& Economic Statistics, 20(3), 339-350. http://dx.doi.org/10.1198/073500102288618487

Engle, R. F., \& Granger, C. (1987). Co-integration and error correction: Representation, estimation, and testing. Econometrica, 55(2), 251-276. http://dx.doi.org/10.2307/1913236

Engle, R. F., Ito, T., \& Lin, W. (1990). Meteor showers or heat waves? Heteroscedastic intraday volatility in the foreign exchange market. Econometrica, 58(3), 525-542. http://dx.doi.org/10.2307/2938189

Engle, R. F., \& Kroner, K. F. (1995). Multivariate simultaneous generalized ARCH. Econometric Theory, 11(1), 122-150. http://dx.doi.org/10.1017/S0266466600009063

Eun, C. S., \& Shim, S. (1989). International transmission of stock market movements. Journal of Financial and Quantitative Analysis, 24(2), 241-256. http://dx.doi.org/10.2307/2330774

Forward Market Commission, Media release. (2011). Retrieved from http://www.fmc.gov.in/docs/press\%20note/A\%20brief\%20overview\%20of\%20the\%20 major\%20developments\%20in\%20the\%20commodity\%20futures\%20April\%202011.pd $\mathrm{f}$

Fung, G. H., Leung, W. K., \& Xu, X. E. (2001). Information role of US futures trading in a global financial market. Journal of Futures Markets, 21(11), 1071-1090. http://dx.doi.org/10.1002/fut.2105

Fung, G. H., Leung, W. K., \& Xu, X. E. (2003). Information flows between the US and China commodity futures trading. Review of Quantitative Finance and Accounting, 21(3), 267-285. http://dx.doi.org/10.1023/A:1027384330827

Fung, G. H., Liu, Q., \& Tse, Y. M. (2010). The information flow and market efficiency between the US and Chinese copper and aluminum futures markets. Journal of Futures Markets, 30(12), 1192-1209. http://dx.doi.org/10.1002/fut.20474

Gagnon, 1., \& Karolyi, A. G. (2006). Price and volatility transmisison across borders. Financial Markets, Institutions and Instruments, 17(3), 107-158. http://dx.doi.org/10.1111/j.1468-0416.2006.00115.x 
Garbade, K. D., \& Silber, W. L. (1979). Dominant and satellite: A study of dually-traded securities. Review of Economics and Statistics, 61(3), 455-460. http://dx.doi.org/10.2307/1926079

Ge, Y., Wang, H. H., \& Ahn, S. K. (2008). Implication of Cotton Price Behavior on Market Integration. Proceedings of the NCCC-134 Conference on applied commodity price analysis, forecasting, and market risk management, St. Louis.

Ghosh, N. (2009a). Issues and concerns of commodity derivative markets in India: An agenda for research. Commodity Vision, 3(4), 8-19.

Ghosh, N. (2009b). Market microstructure in the Indian context. Commodity Vision, 2(4), 1017.

Ghosh, N. (2010). Role of thin commodity futures markets in physical market price making: An analysis of wheat futures in India in the post-ban era. Takshashila Academia of Economic Research, TAER. Working Paper No.6, 1-16.

Glynn, J., Perera, N., \& Verma, R. (2007). Unit root tests and structural breaks: A survey with applications. Journal of Quantitative Methods for Economics and Business Administration, 3(1), 63-79.

Gregory, A. W., \& Hansen, B. E. (1996). Residual-based tests for cointegration in models with regime shifts. Journal of Econometrics, 70(1), 99-126. http://dx.doi.org/10.1016/0304-4076(69)41685-7

Hamao, Y. R., Masulis, R. W., \& Ng, V. K. (1990). Correlation in price changes and volatility across International stock markets. Review of Financial Studies, 3(2), 281-307. http://dx.doi.org/10.1093/rfs/3.2.281

Hasbrouck, J. (1995). One security, many markets: Determining the contributions to price discovery. Journal of Finance, 50(4), 1175-1199. http://dx.doi.org/10.1111/j.1540-6261.1995.tb04054.x

Hua, R., \& Chen, B. (2007). International linkages of the Chinese futures markets. Applied Financial Economics, 17(6), 1275-1287. http://dx.doi.org/10.1080/09603100600735302

International Monetary Fund, (IMF). (2012). World economic outlook database., April) $\begin{array}{lllll}\text { Retrieved } & 10 & \text { May } & 2012 & \text { from }\end{array}$ http://www.imf.org/external/pubs/ft/weo/2012/01/index.htm

Johansen, S., \& Juselius, K. (1992). Testing structural hypotheses in a multivariate cointegration analysis of the PPP and the UIP for UK. Journal of Econometrics, 53(1-3), 211-244. http://dx.doi.org/10.1016/0304-4076(92)90086-7

Kabra, K. N. (2007). Commodity futures in India. Economic and Political Weekly, 42(31), $1163-1169$.

Kao, C. W., \& Wan, J. Y. (2009). Information transmission and market interactions across 
the Atlantic-An empirical study on the natural gas market. Energy Economics, 31(1), 152-161. http://dx.doi.org/10.1016/j.eneco.2008.07.007

Karmakar, M. (2009). Price discoveries and volatility spillovers in S\&P CNX nifty future and its underlying index CNX nifty. Vikalpa, 34(2), 41-56.

King, M. A., \& Wadhwani, S. (1990). Transmission of volatility between stock markets. The Review of Financial Studies, 3(1), 5-33. http://dx.doi.org/10.1093/rfs/3.1.5

Koutmos, G., \& Booth, G. G. (1995). Asymmetric volatility transmission in international stock markets. Journal of International Money and Finance, 14(6), 747-762. http://dx.doi.org/10.1016/0261-5606(95)00031-3

Kumar, B., \& Pandey, A. (2011). International linkages of the Indian commodity futures markets. Modern Economy, 2(3), 213-227. http://dx.doi.org/10.4236/me.2011.23027

Kumar, S. (2004). Price discovery and market efficiency: Evidence from agricultural commodities futures markets. South Asian Journal of Management, 11(2), 32-47.

Lee, K. C., Fung, H. G., \& Liao, T. L. (2009). Day-of-the-week effects in the US and Chinese commodity futures markets. Review of Futures Markets, 18(1), 27-53.

Lihara, Y., Kato, K., \& Tokunaga, T. (1996). Intraday return dynamics between the cash and the futures markets in Japan. Journal of Futures Markets, 16(2), 147-162. http://dx.doi.org/10.1002/(SICI)1096-9934(199604)16:2<147::AID-FUT2>3.0.CO;2-K

Lin, S. X., \& Tamvakis, M. N. (2001). Spillover effects in energy futures markets. Energy Economics, 23(1), 43-56. http://dx.doi.org/10.1016/S0140-9883(00)00051-7

Lin, W. L., Engle, R. F., \& Ito, T. (1994). Do bulls and bears move across borders? International transmission of stock returns and volatility. The Review of Financial Studies, 7(3), 507-538. http://dx.doi.org/10.1093/rfs/7.3.507

Ling, S., \& McAleer, M. (2003). Asymptotic theory for a vector ARMA-GARCH model. Econometric Theory, 19(2), 280-310. http://dx.doi.org/10.1017/S0266466603192092

Liu, Q., \& An, Y. (2011). Information transmission in informationally linked markets: Evidence from US and Chinese commodity futures markets. Journal of International Money and Finance, 30(5), 778-795. http://dx.doi.org/10.1016/j.jimonfin.2011.05.006

Low, W. H. A., Muthuswamy, J., \& Webb, I. R. (1999). Arbitrage, cointegration, and the joint dynamics of prices across commodity futures auctions. Journal of Futures Markets, 19(7),

799-815. http://dx.doi.org/10.1002/(SICI)1096-9934(199910)19:7<799::AID-FUT4>3.0.CO;2-5

Mahalik, K. M., Acharya, D., \& Babu, S. M. (2010). Price discovery and volatility spillovers in futures and spot commodity markets: Some empirical evidence from India. IGIDR Proceedings/Project Reports Series, 062-10.

Naik, G., \& Jain, S. K. (2002). Indian agricultural commodity futures market. Economic and 
Political Weekly, 37(30), 3161-3173.

$\mathrm{Ng}$, A. (2000). Volatility spillover effects from Japan and the US to the Pacific-Basin. Journal of International Money and Finance, 19(2), 207-233. http://dx.doi.org/10.1002/(SICI)1096-9934(199910)19:7<799::AID-FUT4>3.0.CO;2-5

Roope, M., \& Zurbruegg, R. (2002). The intraday price discovery process between the Singapore exchange and Taiwan futures exchange. Journal of Futures Markets, 22(3), 219-240. http://dx.doi.org/10.1002/fut.2215

Ross, S. A. (1989). Information and volatility: The no-arbitrage martingale approach to timing and resolution irrelevancy. Journal of Finance, 44(1), 1-17. http://dx.doi.org/10.1111/j.1540-6261.1989.tb02401.x

Roy, A. (2008). Dynamics of spot and futures markets in Indian wheat market: Issues and implications. Indian Institute of Management, Ahmedabad.

Roy, S., \& Dey, K. (2009). Current status of derivative products in India: An overview. Teaching note, Institute of Rural Management, Anand, 1-12.

Sadorsky, P. (2012). Correlations and volatility spillovers between oil prices and the stock prices of clean energy and technology companies. Energy Economics, 34(1), 248-255. http://dx.doi.org/10.1016/j.eneco.2011.03.006

Susmel, R., \& Engle, R. F. (1994). Hourly volatility spillovers between international equity markets. Journal of International Money and Finance, 13(1), 3-25. http://dx.doi.org/10.1016/0261-5606(94)90021-3

Thomas, S., \& Karande, K. (2001). Price discovery across multiple spot and futures markets. IGIDR Working Paper, Mumbai.

Tomek, W. G. (1980). Price behavior on a declining terminal market. American Journal of Agricultural Economics, 62(3), 434-445. http://dx.doi.org/10.2307/1240198

Tse, Y. (1998). International linkages in Euro mark futures markets: Information transmission and market integration. Journal of Futures Markets, 18(2), 129-149. http://dx.doi.org/10.1002/(SICI)1096-9934(199804)18:2<129::AID-FUT1>3.0.CO;2-K

Tse, Y. (1999). Price discovery and volatility spillovers in the DJIA index and futures market. Journal of Futures Markets, 19(8), 911-930. http://dx.doi.org/10.1002/(SICI)1096-9934(199912)19:8<911::AID-FUT4>3.0.CO;2-Q

Wang, P. J. (2008). Financial econometrics: Methods and models. Routledge, London. http://dx.doi.org/10.4324/9780203892879

Xu, X. E., \& Fung, H. G. (2005). Cross-market linkages between US and Japanese precious metals futures trading. International Finance Markets, Institutions and Money, 15(2), 107-124. http://dx.doi.org/10.1016/j.intfin.2004.03.002

Zivot, E., \& Andrews, D. W. K. (1992). Further evidence on the great crash, the oil price 
shock, and the unit-root hypothesis. Journal of Business Economics and Statistics, 10(3), 251-270.

\section{Notes}

Note 1. Gagnon and Karolyi (2006) could be a good reference in this regard.

Note 2. This study provides a detailed review of unit root tests with structural breaks.

Note 3. For further details, Chan et al. (1991) could be a good reference on the need to study the volatility spillovers.

Note 4. For example, MCX measures the futures lot in $\mathrm{Rs} / \mathrm{Kg}$ terms for aluminum, copper, and zinc, while LME and SHFE trade lots in USD/ton and CNY/ton terms. Similarly, the unit of trade is different among the examined markets for precious metals. Spot market data for USD/rupee currency has been downloaded from the Reserve Bank of India website, and for USD/Chinese yen, the data have been extracted from the Bloomberg database.

Note 5. Sample commodities have been calculated using the first difference of the log price series multiplied by 100 .

Note 6. Due to space constraint, we have not mentioned the results. Howere, results are available upon request.

\section{Copyright Disclaimer}

Copyright reserved by the author(s).

This article is an open-access article distributed under the terms and conditions of the Creative Commons Attribution license (http://creativecommons.org/licenses/by/3.0/). 